\title{
Az óvoda-iskola átmenet óvodapedagógusok, tanítók és szülők szemén keresztül
}

\author{
Gyurcsik Anita \\ Szegedi Tudományegyetem Neveléstudományi Doktori Iskola
}

\begin{abstract}
Absztrakt
Ez a tanulmány egy feltáró jellegü kutatás bemutatásáról szól, mely későbbi nagymintás adatfelvételek megtervezéséhez szolgál alapul. Félig strukturált interjúkat készítettem óvodapedagógusokkal $(\mathrm{N}=5)$, tanítókkal $(\mathrm{N}=5)$ és első osztályos gyermeket nevelő szülőkkel ( $\mathrm{N}=5)$ az óvoda-iskola átmenet értelmezésük és gyakorlatuk feltárása céljából. A válaszadók hasonlóan látják az óvoda-iskola átmenet során megjelenő nehézségek egy részét, ugyanakkor ezek lehetséges megoldásait illetően nem kaptam határozott válaszokat. Eltérő képességeket tartanak fontosnak az iskolakezdés szempontjából, illetve az iskolaérettség megállapítására csak az adott intézményben alkalmazott módszereket ismerik. Elmondásuk szerint az óvoda-iskola átmenetet a leendő tanító és az iskola megismertetésével próbálják segíteni. Az interjúalanyok hasonló intézményi és szülői feladatokat azonosítottak az átmenet megsegítésében. Az eredményeim irányt mutathatnak a szülői nézetek érvekkel való formálásához, illetve a pedagógusok munkájának, eredményességének elősegítéséhez.
\end{abstract}

Kulcsszavak: óvoda-iskola átmenet, iskolaérettség, stakeholderek nézetei, iskolakezdés, átmenet az iskolába

\section{Bevezetés}

Az utóbbi években erőteljes kutatói figyelem irányult a kora gyermekkori fejlődés és annak hosszabb távú hatásainak megismerésére (Józsa et al., 2019). Különböző longitudinális kutatások (például Heckman, 2011) rámutattak arra, hogy az ebbe a szakaszba történő beruházások gazdasági megtérülést eredményeznek. Ezenfelül az is nyilvánvaló, hogy az iskolai sikeresség meghatározó jelentőségű a későbbi életpályát tekintve. Az iskolai sikerességet nagymértékben meghatározza, hogy az iskolába milyen fejlettségi szinttel lépnek be a gyerekek (Józsa et al., 2019). Hazánkban számos eljárást dolgoztak ki a gyermekek fejlettségi állapotának feltárására. Közülük a Diagnosztikus Fejlődésvizsgáló és Kritériumorientált Fejlesztő Rendszer (továbbiakban: DIFER) tesztjeivel végzett longitudinális kutatások (például Józsa, 2004, 2007) bebizonyították, hogy az iskolát megkezdő gyermekek ötöde nem éri 
el az iskolai tanuláshoz szükséges optimális fejlettségi szintet, így számukra nagy kihívást, nehézséget jelent az iskolai tanulás megkezdése. Továbbá az átmenetet a két intézmény között meghúzódó különbségek is megnehezítik (Kende \& Illés, 2007).

A nemzetközi szakirodalom (Hair et al., 2006) felhívja arra a figyelmet, hogy a stakeholderek ${ }^{1}$ iskolakezdéssel kapcsolatos nézeteinek feltárása kiemelten fontos, mivel a megszerzett információk felhasználásával segíthető az óvoda-iskola átmenet. Ennek következtében a nemzetközi szakirodalomban gyakori a stakeholderek óvoda-iskola átmenettel kapcsolatos nézeteinek feltárása (Correia \& Marques-Pinto, 2016). Tanulmányomban ezeket nem tekintem át,s mivel az oktatási rendszerek eltérő felépítése miatt az eredményeik kutatásom szempontjából kevésbé relevánsak.

A téma jelentősége ellenére hazánkban szerényebb kutatói figyelem irányul a stakeholderek óvoda-iskola átmenet értelmezésének és gyakorlatának megismerésére. Ismereteim szerint a kérdés Szabó Mária (2005), Kende Anna és Illés Anikó (2007), illetve Nagy Annamária (2018) pedagógusokkal végzett kutatásaiban jelenik meg. A szülők nézeteit hazánkban még nem tárták fel, holott jól ismert a szülők óvoda-iskola átmenettel kapcsolatos nézeteinek megismerésének fontossága. Antal Judit (2013) kiemeli, hogy a családdal való együttmüködés nélkül csökken a nevelési-oktatási intézmények eredményessége. Ráczné Varga Gyöngyi (2007) a gyermekek iskolaérettségében a szülők elsődleges szerepét hangsúlyozza. Futó Judit (2013) úgy látja, hogy a gyermekek iskolára való felkészítésében a szülők meggyőződései fontos szerepet játszanak.

Nem ismerek olyan magyarországi kutatást, amely az óvodapedagógusok, a tanítók és a szülők óvoda-iskola átmenettel kapcsolatos nézeteinek megismerésével foglalkozik. Ezért tanulmányom célja az óvodapedagógusok, a tanítók és az első osztályos gyermekeket nevelő szülők (1) óvoda-iskola átmenet és (2) iskolaérettség értelmezésének feltárása; (3) az átmenetet segítő gyakorlatok megismerése; illetve (4) az intézményi és a szülői feladatok azonosítása.

Tanulmányom több stakeholdercsoportra kiterjedő kvantitatív vizsgálat előkészítéseként öt óvodapedagógussal, öt tanítóval és öt első osztályos gyermeket nevelő szülővel készített féligstrukturált interjú elemzését mutatja be. Az elméleti áttekintésben a stakeholderek óvoda-iskola átmenettel kapcsolatos vélekedését feltáró hazai kutatásokat foglalom össze. Ezt követően kutatásom részleteit, majd eredményeit közlöm.

Eredményeimből messzemenő következtetések nem vonhatók le, ugyanakkor néhány jellegzetesség már ezekből is kirajzolódik. A vizsgált stakeholderek az óvoda-iskola átmenet során felmerülő nehézségeket hasonlóan látják, noha ezek lehetséges megoldásai nem foglalkoztatják őket. Az iskolakezdéshez szükséges képességeket eltérően ítélik meg. Úgy tűnik, hogy az iskolaérettség mérésére szolgáló eljárásokat kevésbé ismerik. Az átmenet so${ }^{1}$ Az óvoda-iskola átmenet során érintett egyes szereplők például a pedagóguscsoportok vagy a,
szülők. 
rán az intézményváltásra fókuszálnak; a képességfejlesztésről nem beszéltek. Hasonlóan látják az intézményi és a szülői feladatokat. A stakeholderek óvoda-iskola átmenet értelmezésének és gyakorlatának megismerése rámutathat arra, hogy milyen irányban lenne érdemes segítséget kínálni a szülői nézetek érvekkel való formálásához, illetve a pedagógusok munkájának, eredményességének elősegítéséhez.

\section{A stakeholderek óvoda-iskola átmenettel kapcsolatos vélekedését feltáró hazai kutatások}

A stakeholderek óvoda-iskola átmenettel kapcsolatos vélekedését feltáró hazai kutatások rendszerezéséhez fontos röviden felidéznem a vizsgált téma két alapfogalmát: 1 . az óvoda-iskola átmenetet és 2 . az iskolaérettséget, illetve a tanulmány írásakor hatályos, az iskolakezdésre vonatkozó magyarországi törvényi szabályozást.

$\mathrm{Az}$ átmenet azt a folyamatot jelenti, amikor a gyermek a nevelés-oktatás egyik szintjéről átkerül egy másikra, ezáltal az egyik környezetből egy másikba kerül (Fabian, 2007). Ezen belül az óvoda-iskola átmenet az ötéves és a hétnyolc éves kor között húzódik meg, mely kulcskérdése az, hogy a gyermek megfelelő mértékben érett-e az iskolára (Páli, 1997). A nemzetközi szakirodalom (Kagan et al., 1995; Commodari, 2013) az iskolakezdést az alábbi területek megfelelő szintű fejlettségével azonosítja: 1 . kognitív terület; 2 . szociális és érzelmi terület; 3 . motoros terület, illetve 4 . fizikai-testi fejlettség.

A hazai szakirodalomban az iskolaérettség mellett az iskolára való alkalmasság (Mérei \& V. Binét, 1978) és az iskolakészültség (Nagy, 1980) fogalmának a használata is jellemző. Ezek személetükben térnek el egymástól. Az Óvodai nevelés országos alapprogramja $(2012)^{2}$ a testileg, a lelkileg és a szociálisan egészségesen fejlődő gyermek óvodáskor végi jellemzőit fejti ki részletesen.

A tanulmány írásakor hatályos 2011. évi CXC. törvény a Nemzeti közne-

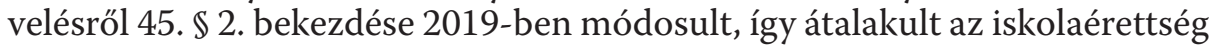
megállapításának folyamata. A módosítást követően „tankötelessé válnak a gyermekek abban az évben, melynek augusztus 31. napjáig a hatodik életévüket betöltik". A szülő az adott év január 15-éig kérvényezheti az Oktatási Hivatalnál, hogy a gyermeke egy évvel később kezdje meg az iskolát. Erről a szakértői bizottság dönt.

Az Alapprogram (2012) leírja, hogy az óvodapedagógusok feladata a gyermekek fejlődésének nyomon követése, melyhez felhasználhatnak különböző módszereket, eszközöket. A Magyarországon alkalmazott iskolaérettség-vizsgálati módszerek összehasonlítását Gerebenné Várbíró Katalin és Vidákovich Tibor (1997) közölte. Majd Apró Melinda (2013) elemzése a magyarországi óvodákban alkalmazott iskolaérettség-vizsgálati módszerek gyakoriságát tárta fel. Újabban Gyurcsik Anita, Fehér Orsolya és Földi Fan-

\footnotetext{
${ }^{2}$ Továbbiakban: Alapprogram.
} 
ni (2017) készített egy összehasonlító tanulmányt a Magyarországon széles körben alkalmazott DIFER-programcsomag és a Szerbiában használt TIP-1 mérőeszköz főbb hasonlóságairól és különbségeiről.

Hazánkban a stakeholderek óvoda-iskola átmenettel kapcsolatos nézetei kevésbé feltártak. Ez Szabó Mária (2005), Kende Anna és Illés Anikó (2007), valamint Nagy Annamária (2018) pedagógusokkal végzett kutatásaiban jelent meg kutatási kérdésként. Ezek főbb sajátosságait az 1. táblázatban rendszereztem.

Szabó (2005), illetve Kende és Illés (2007) kutatása a 2000-es évek közepén jelent meg. Szabó Mária (2005) tanulmányának fó célja a kezdő szakasz helyzetének feltárása, ezen belül az óvoda-iskola átmenet helyzetét és a korai iskolai kudarcok okait vizsgálja. Ennek érdekében óvodapedagógusok, tanítók, illetve nevelési tanácsadók munkatársai körében végzett kérdőíves vizsgálatot. Kende Anna és Illés Anikó (2007) kutatásának fő célja annak megismerése, hogy a rugalmas beiskolázás hozzájárul-e az óvoda-iskola átmenet során felmerülő nehézségek csökkentéséhez. Vizsgálatukban azt is feltárták, hogy mi okozza az átmenet során a nehézségeket. Kutatásukban második osztályosokat tanító pedagógusok körében végeztek írásbeli és szóbeli kikérdezést. Nagy Annamária (2018) óvodapedagógusokkal és tanítókkal készített interjúinak célja annak megismerése, hogy a Vajdaságban, Magyarországon és Erdélyben az eltérő óvoda-iskola átmenet gyakorlatától függetlenül milyen módszerek és eszközök azonosíthatók a harmonikus átmenet legalapvetőbb elemeiként.

\section{1. táblázat}

A stakeholderek óvoda-iskola átmenettel kapcsolatos nézeteit vizsgáló hazai kutatások sajátosságai - idörendi sorrendben

\begin{tabular}{|l|l|l|l|}
\hline \multicolumn{1}{|c|}{ Tanulmány } & \multicolumn{1}{c|}{ Mire irányul } & \multicolumn{1}{c|}{ Minta } & \multicolumn{1}{c|}{ Módszer } \\
\hline Szabó Mária, 2005 & $\begin{array}{l}\text { kezdő szakasz hely- } \\
\text { zete }\end{array}$ & $\begin{array}{l}\text { óvodapedagógusok, } \\
\text { tanítók, nevelési } \\
\text { tanácsadók munka- } \\
\text { társai }\end{array}$ & kérdóív \\
\hline $\begin{array}{l}\text { Kende Anna \& Illés } \\
\text { Anikó, 2007 }\end{array}$ & $\begin{array}{l}\text { rugalmas beiskolá- } \\
\text { zás szerepe }\end{array}$ & tanítók & interjú; kérdőív \\
\hline $\begin{array}{l}\text { Nagy Annamária, } \\
2018\end{array}$ & $\begin{array}{l}\text { harmonikus óvoda- } \\
\text { iskola átmenetet }\end{array}$ & $\begin{array}{l}\text { óvodapedagógusok, } \\
\text { tanítók }\end{array}$ & $\begin{array}{l}\text { interjú; metafo- } \\
\text { ravizsgálat }\end{array}$ \\
\hline
\end{tabular}

Szabó Mária (2005), illetve Kende Anna és Illés Anikó (2007) kutatása hasonló kérdésekre kereste a választ. Mindkét elemzés feltárta a stakeholderek nézeteit az iskolakezdést megnehezítő tényezőkről. Az iskolakezdést megnehezítő tényezők kapcsán eltérő eredményeket kaptak. Szabó Mária (2005) vizsgálata alapján a különböző stakeholderek eltérően ítélik meg, hogy az iskolakezdést mely tényezők nehezítik meg. A vizsgálatába bevont óvodapedagógusok szerint az iskolakezdést elsősorban a tanulási motiválatlanság nehezíti meg, ezzel szemben a tanítók szerint elsősorban a szülői tá- 
mogatás hiánya jelenti a fő nehézséget. A nevelési tanácsadók munkatársai a túlméretezett tantervi követelményeket és a feszített tanulási tempót jelölték meg fő nehezítő tényezőként az iskolakezdéssel kapcsolatban. Kende és Illés (2007) vizsgálatában a tanítók szerint az iskolakezdést megnehezítő legfőbb ok az éretlenség, ezen belül a szociális éretlenség, az értelmi képességek gyengesége és a testi fejletlenség.

Nagy József munkái $(1980 ; 1986)$ alapján nyilvánvaló, hogy a személyiség különböző komponenseinek fejlődése akár több évig is eltarthat, ennek következtében minden gyermek eltérő fejlődést mutat. Nagy József eredményei (2003) rávilágítottak arra, hogy a kritikus kognitív képességek fejlettsége nagymértékben meghatározza a tanulási eredményességet, azonban a kognitív képességek optimális fejlettségi szintjét a gyerekek eltérő életkorban érik el. Az eredményei rámutattak arra is, hogy a hatéves gyermekek esetén akár ötévnyi fejlettségbeli eltérés is kimutatható, így magas egyéni különbségekkel kezdik meg a gyermekek az iskolát.

Szabó Mária (2005) arra a megállapításra jutott, hogy az óvodapedagógusok és a tanítók más szempontok alapján ítélik meg az iskolaérettséget, ugyanis az óvodapedagógusok a tanuláshoz közvetlenül szükséges képességeket tartják az iskolakezdés szempontjából a legfontosabbnak. Ilyen például az, hogy a gyermekek képesek legyenek a figyelmüket fenntartani, értsék meg a beszédet és képesek legyenek válaszok megfogalmazására. Az általa kikérdezett tanítók ezeken kívül a szociális képességek megfelelő fejlettségét is elvárják az iskolát megkezdő gyermekektől, például a helyes viselkedést, a szabályokhoz és a társakhoz való alkalmazkodást.

Nagy Annamária (2018) a pedagógusokkal készített interjúk elemzése során a harmonikus átmenet legfőbb támogatójaként öt fogalmi tartományt azonosított: 1 . az érintett pedagógusok együttműködését, 2 . komplex program létrehozását és integrálását az iskolai oktatásba, 3. a pedagóguskompetencia folyamatos fejlesztését 4 . a változatos módszertani elemek használatát és 5 . a holisztikus fejlesztést.

Az elméleti áttekintésből levonható fó tanulság az, hogy a stakeholderek óvoda-iskola átmentettel kapcsolatos nézeteit feltáró hazai kutatások a látható különbségekre fókuszálnak. Nincsenek információink a szülői nézetekről, az egymás gyakorlatainak ismeretéről, illetve az egymás elvárásainak ismeretéről és érzékeléséről sem. Tanulmányom következő részében az empirikus kutatás bemutatására kerül sor, majd eredményeimet ismertetem.

\section{Az empirikus vizsgálat bemutatása}

\section{Célok}

A tanulmány elsődleges célja, több stakeholdercsoportra kiterjedő surveytípusú vizsgálat előkészítéseként végzett interjúk elemzésének bemutatása, a stakeholderek óvoda-iskola átmenet értelmezésének és gyakorlatának fel- 
tárása. Ezen belül négy témakör feltárása a kutatás célja: a stakeholderek (1) óvoda-iskola átmenet és, (2) iskolaérettség értelmezésének, (3) az átmenetet segítő gyakorlatoknak, illetve (4) az intézményi és a szülői feladatoknak leírása.

\section{Módszerek és minta}

Az adatgyüjtés során a kényelmi mintavétellel felkért óvodapedagógusokat $(\mathrm{N}=5)$, tanítókat $(\mathrm{N}=5)$ és első osztályos gyermekeket nevelő szülőket $(\mathrm{N}=5)$ félig strukturált interjúk segítségével kérdeztem ki. A mintába került óvodapedagógusok és tanítók egy magyar nagyváros tíz különböző köznevelési intézményében dolgoznak. A pedagógusminta fóbb jellemzőit a 2. táblázat foglalja össze. Ebben a táblázatban az utolsó oszlop azt jelöli, hogy a megkérdezett óvodapedagógusok hány alkalommal foglalkoztak nagycsoportos óvodások nevelésével, illetve a megkérdezett tanítók hány alkalommal tanítottak első osztályos gyermekeket. A szülői mintát olyan édesanyák alkották, akik eltérő számú gyermeket nevelnek. A szülői minta közös jellemzője, hogy gyermekeik közül egy-egy az adatfelvétel idején első osztályos tanuló volt, aki egy-egy magyar nagyváros öt különböző köznevelési intézményében tanult. A szülői minta főbb jellemzőit a 3. táblázat közli.

2. táblázat

A vizsgálatba bevont pedagógusok fóbb jellemzöi

\begin{tabular}{|c|c|c|c|c|}
\hline Minta & Kódszám & Nem & $\begin{array}{l}\text { Szakmai ta- } \\
\text { pasztalat évek- } \\
\text { ben }\end{array}$ & $\begin{array}{l}\text { Átmenet során } \\
\text { érintett gyer- } \\
\text { mekkel foglal- } \\
\text { kozás alkalma- } \\
\text { inak száma }\end{array}$ \\
\hline \multirow{5}{*}{$\begin{array}{l}\text { Óvoda- } \\
\text { pedagógus }\end{array}$} & 1 & Nő & $0-4$ & 1 \\
\hline & 2 & Nő & $5-9$ & 2 \\
\hline & 3 & Nő & $5-9$ & 2 \\
\hline & 4 & Nő & $15-19$ & 4 \\
\hline & 5 & Nő & $20-24$ & 5 \\
\hline \multirow{5}{*}{ Tanító } & 1 & Nő & $5-9$ & 2 \\
\hline & 2 & Férfi & $10-14$ & 3 \\
\hline & 3 & Nő & $15-19$ & 4 \\
\hline & 4 & Nő & $15-19$ & 4 \\
\hline & 5 & Nő & $25-29$ & 7 \\
\hline
\end{tabular}


3. táblázat

A vizsgálatba bevont szülöi minta föbb jellemzői

\begin{tabular}{|c|c|c|c|c|}
\hline \multirow{4}{*}{ Minta } & Kódszám & $\begin{array}{c}\text { Legmagasabb } \\
\text { iskolai } \\
\text { végzettség }\end{array}$ & $\begin{array}{c}\text { Gyermekek } \\
\text { száma }\end{array}$ & $\begin{array}{c}\text { Az átmenet } \\
\text { során érintett } \\
\text { gyermek száma } \\
\text { a testvérsorban }\end{array}$ \\
\hline \multirow{4}{*}{ Szülő } & 1 & érettségi & 2 & 1 \\
\cline { 2 - 5 } & 2 & érettségi & 1 & 1 \\
\cline { 2 - 5 } & 3 & fóiskola & 3 & 2 \\
\cline { 2 - 5 } & 4 & fóiskola & 1 & 1 \\
\cline { 2 - 5 } & 5 & egyetem & 2 & 2 \\
\hline
\end{tabular}

\section{Az adatgyüjtés és adatelemzés eljárásai}

Az intézményvezetőktől e-mailben kértem engedélyt adatfelvételre, majd a felkért pedagógusokkal és szülőkkel telefonon és/vagy e-mailben egyeztettem az adatfelvétel részleteit. A vizsgálatba bevont pedagóguscsoportok és szülők önként vettek részt a kutatásban, ismerték a kutatás céljait. Az interjúalanyokat egyenként szóban kérdeztem ki előre összeállított vázlat alapján. Egy beszélgetés 60-90 percig tartott. Az interjúkról hangfelvételek készültek. A pedagógusok szóbeli kikérdezése 2019 decemberében valósult meg üres óvodai csoportszobában vagy iskolai tanteremben. A szülőkkel 2020 áprilisában videóhívásban beszélgettem. A pedagógusokkal és a szülőkkel készített interjúk négyszemközt valósultak meg, a beszélgetéseket semmi sem zavarta. A kényelmi mintavétel során felkért interjúalanyok a kutatásban szívesen vettek részt, örömmel mesélték el a tapasztalataikat. Az egyes kérdésekre adott válaszokat összehasonlítottam, majd összefoglaltam. Tanulmányom következő részében a feltárt témakörök mentén haladva mutatom be az eredményeket.

\section{Eredmények}

\section{A kikérdezett stakeholderek óvoda-iskola átmenet értelmezése}

Az interjú első része a stakeholderek óvoda-iskola átmenet értelmezését tárta fel. Ezen belül az óvoda-iskola átmenet fogalmára és az óvoda-iskola átmenet során felmerülő nehézségekre vonatkozóan tettem fel kérdéseket.

Az interjúkból kiderült, hogy az óvoda-iskola átmenetet a gyakorló pedagógusok és a szülők is intézményváltási folyamatként értelmezik. Ennek segítése az óvodapedagógusok és a szülők számára az óvodában zajló iskolai 
felkészítést foglalja magába, ugyanakkor a megkérdezett tanítók egyöntetű véleménye alapján a folyamat csak az első osztály megkezdésekor indul és az iskolába való beszoktatást jelenti. Tehát az interjúkból az átmenet szűk értelmezése rajzolódott ki, ellenben a koragyermekkori fejlődést leíró hazai szakirodalommal (Nagy, 1980), mely az óvoda-iskola átmenet értelmezésében az intézményváltást és a kritikus fejlődési folyamatokat is figyelembe veszi.

A következő kérdések az óvoda-iskola átmenet során felmerülő nehézségek feltárására, illetve a nehézségek megoldási lehetőségeire vonatkoztak. A válaszadó stakeholderek hasonlóan látják az átmenet során felmerülő nehézségek egy részét: az alaptevékenység, a környezet- és az elvárásrendszer megváltozását, illetve az érintett pedagógusok és szülők együttműködésének hiányát. Azonban az óvodapedagógusok nem említették a tanítók számára nyilvánvaló problémákat a gyerekek önállóságára, illetve szociális készségeire vonatkozóan. Ezek az eredmények részben megegyeznek Szabó Mária (2005), illetve Kende Anna és Illés Anikó (2007) kutatásának eredményeivel - ugyanis az általam kikérdezett stakeholderek nem említették az átmenetet nehezítő tényezők között a tanulási motiválatlanságot és a szülői támogatás hiányát.

Az interjúalanyok a felmerülő problémákra leginkább az iskolától várják a megoldást; kevésbé jellemző, hogy azokat az óvoda és az iskola együttmüködésével oldanák meg. A megoldást leginkább az óvodai környezethez hasonló iskolai környezet megteremtésében, a játékos iskolai foglalkozások bevezetésében, az iskolai elvárások, követelmények csökkentésében, illetve az iskola és a leendő pedagógus megismertetésében látják. (1. függelék)

Az elemzés során összefüggést azonosítottam a pedagógusok pályán eltöltött éveinek száma és az átmenet során felmerülő nehézségek felidézése között - vagyis azok a pedagógusok, akik több alkalommal foglalkoztak óvoda-iskola átmenet során érintett gyermekekkel, több nehézséget soroltak fel, ugyanakkor arra a kérdésre, hogy ezeken melyik intézmény, hogyan tud segíteni nem adtak határozottabb válaszokat, mint a kevesebb szakmai tapasztalattal rendelkező pedagógusok. Továbbá összefüggést találtam az átmenet során érintett gyermek testvérsorban betöltött száma és a szülők által felsorolt átmenetet nehezítő tényezők mennyisége között - vagyis azok a szülők, akiknek az első gyermekük volt az adatfelvétel idején érintett az óvoda-iskola átmenetben sokkal több nehézséget soroltak fel, mint azok, akiknek az idősebb gyermekük már iskolás volt.

A megkérdezett stakeholderek tapasztalatai alapján az óvoda-iskola átmenet során felmerülő nehézségek az első osztály félévének végére általában megszűnnek, akkora sikerül a gyermekeknek az iskola világába beilleszkedni.

\section{A válaszadók iskolaérettség értelmezése}

Az interjú következő részében a stakeholderek iskolaérettség-értelmezését tártam fel. Ezen belül kérdéseim egyrészt arra vonatkoztak, hogy a stakehol- 
derek milyen képességeket tartanak fontosnak az iskolakezdés szempontjából, valamint, hogy milyen módszereket ismernek a gyermekek fejlettségi állapotának feltárására és ezek közül melyiket alkalmazzák az adott intézményben.

Az iskolakezdéshez szükséges képességek esetén egy-egy pedagógus 5-6 konkrét cselekvést sorolt fel (például a gyermek képes érthetően kifejezni önmagát); nem volt jellemző, hogy nagyobb területeket emeltek ki (például kognitív terület). Az óvodapedagógusok 19 különböző iskolakezdéshez szükséges képességet soroltak fel, a tanítók 21-et. Ebből kilenc azonos, melyeket dőlt betűvel emeltem ki a 4. táblázatban.

Szabó Mária (2005) eredményeihez hasonló eredményeket kaptam az iskolakezdéshez szükséges képességek megítélését illetően. A válaszok alapján úgy tűnik, hogy az óvodapedagógusok az iskolakezdés szempontjából a tanuláshoz közvetlenül szükséges képességeket tartják a legfontosabbnak, míg a tanítók ezeken kívül a szociális képességek és a finommozgás megfelelő fejlettségét is kiemelték. (4. táblázat)

4. táblázat

Az iskolakezdéshez szükséges képességek a kikérdezett óvodapedagógusok és tanitók szerint-gyakorisági sorrendben

\begin{tabular}{|l|l|}
\hline \multicolumn{1}{|c|}{ Minta } & Az iskolakezdéshez szülsséges képességek (válaszadók száma) \\
\hline Óvodapedagógusok & $\begin{array}{l}\text { alapvetó ismeretei vannak önmagáról és a családjáról (5) } \\
\text { képes érthetöen kifejezni önmagát (5) } \\
\text { képes az önálló feladatmegoldásra (4) } \\
\text { érdeklödik a számok és a betük iránt (4) } \\
\text { teljesíti a pedagógusok utasításait (4) }\end{array}$ \\
& betartja a szabályokat (4) \\
ismeri az alapvető testrészeket (4) \\
nyitott az új ismeretek iránt (4) \\
megérti a feladatokat és a kérdéseket (4) \\
felismeri a színeket (4) \\
képes válaszolni a feltett kérdésekre (3) \\
felismeri a balról jobbra haladási irányt (3) \\
önellátó az öltözködésben, evésben, mosdóhasználatban (3) \\
felismeri az ok-okozati összefüggéseket (3) \\
a korának megfelelö szókinccsel rendelkezik (3) \\
fenn tudja tartani a figyelmét 20 percig (3) \\
megérti az időbeli összefüggéseket (2) \\
felismeri a hibás kiejtést (2) \\
tud húszig számolni (2)
\end{tabular}




\begin{tabular}{|l|l|}
\hline Tanítók & képes az önálló feladatmegoldásra (5) \\
önellátó az öltözködésben, evésben, mosdóhasználatban (5) \\
képes kapcsolatot kialakítani a társaival (4) \\
megérti a feladatokat és a kérdéseket (4) \\
képes válaszolni a feltett kérdésekre (4) \\
helyesen fogja a ceruzát (4) \\
tudja használni az ollót (4) \\
képes kivárni, hogy sorra kerüljön (4) \\
együttmüködő a társaival (4) \\
képes az emberrajz ábrázolásra (4) \\
képes a vonalon belüli vonalvezetésre (4) \\
tud alapvetö alakzatokat hajtogatni papírból (3) \\
képes gyöngyöket felhúzni egy zsinórra (3) \\
képes érthetöen kifejezni önmagát (3) \\
képes színezni (3) \\
sok mondókát, gyermekdalt ismer (3) \\
a korának megfelelő szókinccsel rendelkezik (3) \\
betartja a szabályokat (2) \\
együttmüködő a pedagógusokkal (3) \\
nyitott az új ismeretek iránt (2) \\
érdeklódik a számok és a betük iránt (2)
\end{tabular}

Összefüggést találtam a tanítók pályán eltöltött éveinek száma és az iskolakezdéshez szükséges képességek megítélése között - vagyis azok a tanítók, akik már legalább négy alkalommal tanítottak első osztályos gyerekeket az iskolakezdéshez szükséges képességek felsorolásakor leginkább olyan tevékenységeket soroltak fel, melyek a gyermekek finommotoros készségeihez kapcsolódnak (például a gyermek tud alapvető alakzatokat hajtogatni papírból), míg ezek kevésbé jelentek meg azoknál a tanítóknál, akik egy vagy két alkalommal tanítottak első osztályban.

A vizsgálatba bevont szülők nem adtak határozott válaszokat arra a kérdésre, hogy mit tud az a gyermek, aki készen áll az első osztályra. Ugyanakkor leginkább a kognitív területhez tartozó képességeket soroltak fel, például a gyermek tud tízig számolni, megérti az összefüggéseket, illetve képes fenntartani a figyelmét hosszabb ideig.

Az iskolaérettség megállapítására használt eszközöket illetően egységes kép rajzolódott ki. Erre a célra az óvodapedagógusok a DIFER-programcsomag tesztjeit (3), illetve Porkolábné Balogh Katalin és munkatársai (1997) által kidolgozott megfigyeléses szempontsort (2) használják. Ezeket gyakran az adott intézményben dolgozó óvodapedagógusok által kidolgozott megfigyeléses szempontsorral egészítik ki. A kikérdezett óvodapedagógusok a használt eszközökön kívül nem tudtak felsorolni egyéb eljárásokat, módszereket az iskolaérettség megállapítására, a gyermekek fejlettségi állapotának feltárására.

A vizsgálatba bevont tanítók elmondása szerint az iskolában iskolaérettségi vizsgálatot nem készítenek, ugyanakkor feltárják a gyermekek képességeit a DIFER-programcsomag tesztjeivel az iskolakezdést követő néhány hétben a fejlesztésre szoruló gyerekek azonosítása céljából. Elmondásuk sze- 
rint osztályonként 1-2 tanuló esetében jellemző, hogy lemaradást azonosítanak az alapkészségeik fejlettségében, mely hátrányt fejlesztő foglalkozásokkal igyekeznek csökkenteni.

A tanulmány írásakor hatályban lévő 13/2018 (VI.16) EMMI rendelet 7 \$ (11) a 2018/2019. tanév rendjéről elöírja az iskoláknak a DIFER-használatát vagyis az iskoláknak kötelező október közepéig kijelölniük azokat a tanulókat, akiknél az elemi alapkészségek fejlesztését hangsúlyosan segíteni kell az óvodából érkezett jelzések és az iskola megkezdésétől szerzett tapasztalatok alapján. Az elemi alapkészségek közé az írásmozgás-koordináció, a beszédhanghallás, a relációszókincs, az elemi számolási készség, a tapasztalati következtetés, a tapasztalati összefüggés-megértés és a szocialitás tartozik (Nagy et al., 2004). Józsa Krisztián (2016) adatai alapján az iskolát megkezdő gyermekek 30 százalékánál szükséges a DIFER-vizsgálat elvégzése és a kritikus elemi készségek fejlesztése.

A kikérdezett szülők az iskolaérettségi vizsgálatokról kevés információval rendelkeztek. Emlékeik szerint az óvodában és az iskolában is feltárták a gyermekek képességeit tesztekkel, ugyanakkor a pedagógusok nem beszélték át a szülőkkel ezek eredményeit. A vizsgálatok részleteit a megkérdezett szülők nem tudták felidézni.

\section{Az óvoda-iskola átmenetet segítö gyakorlatok a kikérdezett stakeholderek szemén keresztül}

Az interjú következő kérdései az átmenet megsegítését célzó gyakorlatokat tárták fel. Arra voltam kíváncsi, hogy az adott intézményben milyen gyakorlatokat alkalmaznak az átmenet megsegítésére, a szülők hogyan vélekednek az intézményi gyakorlatokról, illetve a pedagógusok gyüjtenek-e adatokat az alkalmazott gyakorlatok hatékonyságáról.

Az interjúkból kiderült, hogy a vizsgált intézményekben az óvoda-iskola átmenetet segítő gyakorlatok az új intézmény és a leendő tanító megismertetését célozzák. A kikérdezett pedagógusok nem tekintettek a DIFER-programcsomagra mint az átmenetet segítő lehetőségre.

Az interjúalanyok öt különböző módját sorolták fel az új intézmény és a leendő tanító megismertetésének. (5. táblázat) Ezek gyakoriságát hasonlóan ítélték meg. Emlékeik alapján a leggyakoribb a szülői értekezletek és az iskolai nyílt napok szervezése. A szülői értekezleteken az iskola pedagógiai programjának, céljainak, házirendjének bemutatása és a szükséges tanszerek megismertetése jellemző. Ezenfelül gyakori, hogy az iskolaérettség jellemzőiről előadást tart az iskola gyógypedagógusa, fejlesztőpedagógusa vagy pszichológusa. Jellemző még a leendő első osztályos tanító bemutatása is. Az iskolai nyílt napokon a gyerekeket a leendő tanító körbevezeti az iskolában és részt vehetnek az elsősök tanítási óráin is. Gyakori még, hogy a leendő tanító tavasszal részt vesz néhány óvodai foglalkozáson, ezáltal megismeri a gyermekek közösségben való viselkedését és információkat kérhet az óvodapedagógustól a gyermekekről. Jellemző még a közös óvodai és iskolai ünnepek 
szervezése (például karácsonyi ünnepség), melyek újabb lehetőséget adnak a leendő tanítóval és az iskola épületével való találkozásra. Kisebb arányban jellemző, hogy az iskolakezdést követő első néhány hétben a volt óvodapedagógusok meglátogatják a gyermekeket az iskolában.

5. táblázat

Az új intézmény és a leendö tanitó megismertetésének gyakorisága

\begin{tabular}{|l|c|c|c|c|c|}
\hline \multirow{2}{*}{ Válaszadók } & \multicolumn{4}{|c|}{ Az új intézmény és a leendő tanító megismertetésének módjai } \\
\cline { 2 - 6 } & $\begin{array}{c}\text { Szülői érte- } \\
\text { kezletek }\end{array}$ & $\begin{array}{c}\text { Iskolai nyíltt } \\
\text { nap }\end{array}$ & $\begin{array}{c}\text { Tanító óvo- } \\
\text { dai látoga- } \\
\text { tása }\end{array}$ & $\begin{array}{c}\text { Közös ünne- } \\
\text { pek }\end{array}$ & $\begin{array}{c}\text { Óvoda- } \\
\text { pedagógus } \\
\text { iskolai láto- } \\
\text { gatása }\end{array}$ \\
\hline $\begin{array}{l}\text { Óvoda- } \\
\text { pedagógus }\end{array}$ & 5 & 5 & 3 & 3 & 2 \\
\hline Tanító & 5 & 5 & 2 & 3 & 1 \\
\hline Szülő & 5 & 5 & 3 & 2 & 2 \\
\hline
\end{tabular}

A kikérdezett szülők emlékei szerint az óvoda és az iskola által kínált öszszes programon részt vettek. Ezekről az óvodapedagógustól, az óvodában kihelyezett hirdetőtábláról, az ismerősöktől és/vagy a közösségi média különböző felületein keresztül értesültek. A válaszadó szülők visszatekintve elégedettek a felkínált programok mennyiségével, ugyanakkor a programok minőségét illetően nem alakult ki egységes vélemény. Két szülő az iskolai nyílt nap alkalmával felkészületlennek ítélte meg a gyermekeket fogadó iskolát és a pedagógusokat. Szintén két szülő a szülői értekezletek felépítését kifogásolta, elmondásuk szerint a szülői kérdések megválaszolására már nem jutott idő. Csak egy szülő volt teljes mértékben elégedett az intézmények által kínált programok minőségével. Összességében a kikérdezett szülők úgy érzik, hogy mennyiségileg elegendők a felkínált programok, ugyanakkor a minőségükkel nem teljesen elégedettek.

A kutatásba bevont pedagógusok szerint az intézmények nem gyűjtenek adatokat a programok hatékonyságáról, így nem ismert, hogy ezek valójában mennyire járulnak hozzá az átmenet megkönnyítéséhez.

\section{Az intézményi és a szülöi feladatok megítélése a kikérdezett stakeholderek szerint}

Az interjú utolsó kérdéseiben megkérdeztem a stakeholderektől, hogy az átmenet során milyen feladatokat tulajdonítanak az intézményeknek és a szülőknek. (6. táblázat) A kapott válaszokból összesen öt-öt intézményi és szülői feladatot különítettem el. Az interjúalanyok az intézményi és a szülői feladatokra vonatkozó kérdésekre nem adtak határozott válaszokat. 
Az óvodapedagógusok és a szülők az intézményi feladatok közé sorolták az óvoda és az iskola közötti főbb különbségek gyermekkel történő átbeszélését. Továbbá az összes megkérdezett tanító az intézményi feladatok közé sorolta a leendő első osztályos gyermekek és szüleik megismerését, ugyanakkor ezt az óvodapedagógusok és a szülők kevésbé tartották lényegesnek.

A szülők feladatait hasonlóan látják a kikérdezett stakeholderek. (6. táblázat) A szülők feladatai közé sorolták a rendszeres beszélgetést a gyerekekkel az iskoláról, az iskola és a leendő tanító elvárásainak megismerését, az érdeklődést a pedagógusoktól a gyermekek fejlettségi állapotáról, illetve a kapcsolatfelvételt a tanítóval és az együttmüködésre törekvést. Az óvodapedagógusok és tanítók a szülői feladatok közé sorolták még a pedagógusok tanácsainak és észrevételeinek az elfogadását is, noha a szülők erre nem tekintenek feladatként.

\section{6. táblázat}

Az intézmények és a szülók feladatai az átmenet során a megkérdezett stakeholderek szerint

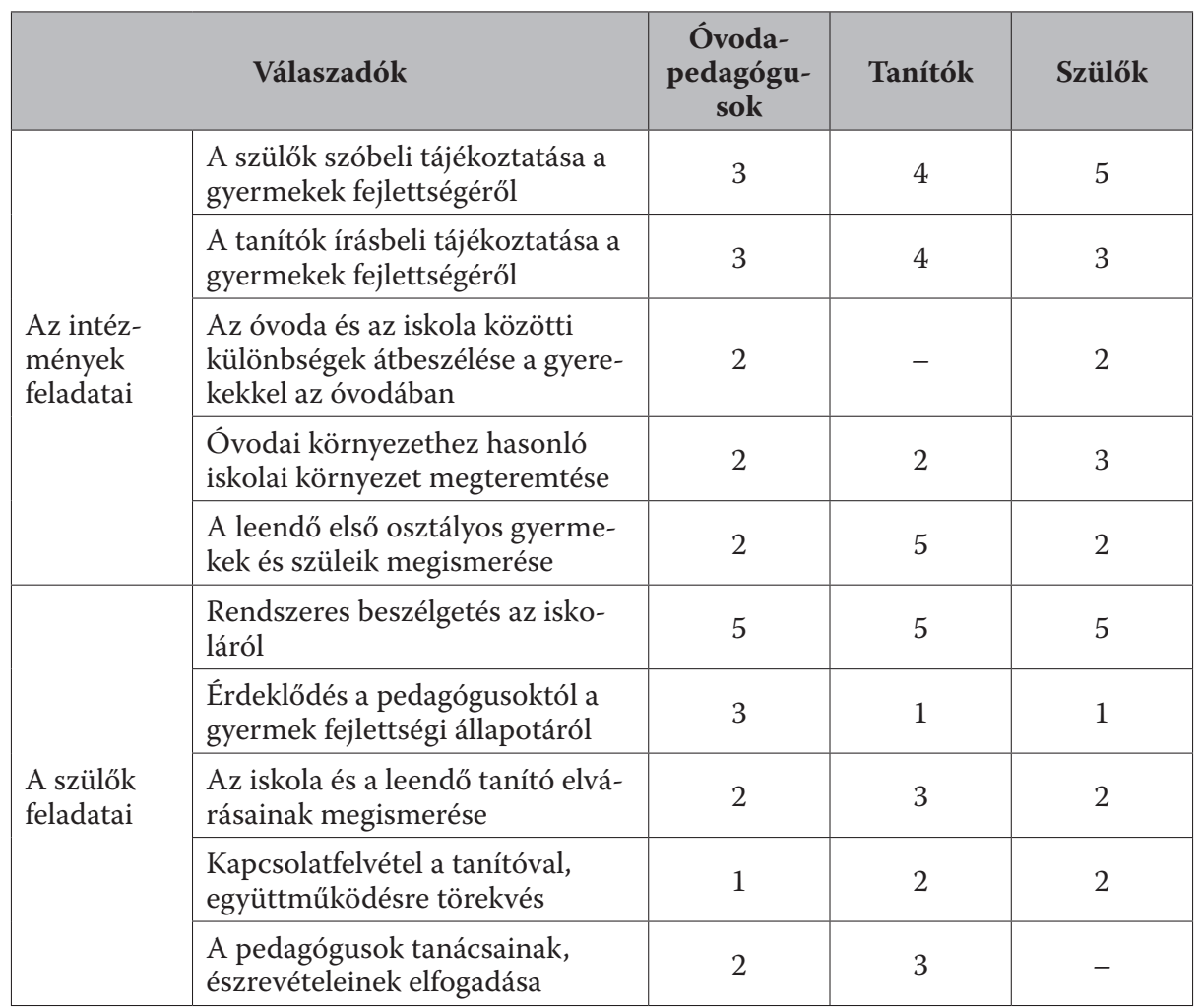




\section{Összegzés}

Tanulmányomban a stakeholderek óvoda-iskola átmenet értelmezését és gyakorlatát tártam fel. A vizsgálatba bevont minta kicsi, így az eredményekből messzemenő következtetések nem vonhatók le, ugyanakkor az eredmények rávilágítanak néhány jellegzetességre. A pedagógusokkal készített interjúkkal hasonló eredményeket kaptam, mint Szabó Mária (2005), Kende Anna és Illés Anikó (2007), valamint Nagy Annamária (2018) kutatásai, bár az eredményeim ezeket kiegészítik, ugyanis rámutatnak olyan tényezőkre, melyek ezekben a kutatásokban nem jelentek meg.

Az interjúkból kirajzolódott, hogy az interjúalanyok az átmenetet szűken értelmezik - vagyis az átmenet során az intézményváltásra fókuszálnak. Az átmenet során felmerülő nehézségek többségét azonosan látják a vizsgálatba bevont stakeholderek, ugyanakkor a tanítók említettek olyan problémákat, melyeket az óvodapedagógusok és a szülők nem. A válaszadók gondolkodás nélkül sorolták fel az óvoda-iskola átmenet során megjelenő nehézségeket. Ez arra utal, hogy ez a kérdés foglalkoztatja őket. Ezzel szemben a problémák lehetséges megoldásaira vonatkozó kérdésekre nem kaptam határozott válaszokat. Ez arra utalhat, hogy ezeken még nem gondolkodtak.

Az iskolakezdéshez szükséges képességek mivolta nem egyértelmű a kikérdezett stakeholderek számára, illetve az iskolakezdés szempontjából eltérő képességeket tartanak fontosnak. Az óvodapedagógusok inkább a tanuláshoz közvetlenül szükséges képességeket tartják fontosnak, míg ezeken kívül a tanítók a szociális és a finommotoros képességek megfelelő fejlettségét is szükségesnek vélik. Úgy tünik, hogy a stakeholderek nincsenek tisztában a többi stakeholder elvárásaival, holott egymás nézeteinek ismerete segíthet a gördülékeny átmenet megvalósításában. Az iskolaérettség mérésére csak az adott intézményben alkalmazott eljárásokat tudták felidézni, egyéb eljárásokat, módszereket nem ismertek.

A megkérdezett stakeholderek az alkalmazott óvoda-iskola átmenetet segítő gyakorlatokat könnyedén felidézték. Ezek a leendő tanító és az iskola megismertetését célozzák. A pedagógusok elmondása szerint az intézmények nem gyüjtenek adatokat ezek hatékonyságáról, így nem tudjuk, hogy ténylegesen hozzájárulnak-e az átmenet és az iskolai tanulás elösegítéséhez. A szülők elégedettek a felkínált programok mennyiségével, noha a minőségüket illetően azonosítottak problémákat.

Az interjúalanyok az intézményi és a szülői feladatokra vonatkozó kérdésekre nem adtak határozott válaszokat, ugyanakkor hasonló feladatokat tulajdonítottak a különböző stakeholdereknek. Ezeknél a kérdéseknél gyakran megismételték ugyanazokat a válaszokat, amelyeket az átmenetet segítő gyakorlatokhoz kapcsolódó kérdéseknél már elmondtak. Ez arra utalhat, hogy nem foglalkoztak még az intézményi- és a szülői feladatok átgondolásával. A vizsgált kérdések és az egyes háttérváltozók között azonosítottam néhány összefüggést, ugyanakkor nagyobb mintás adatfelvételek szükségesek ezek tényleges igazolásához. 
A különböző intézményeket és az átmenet során érintett szülőket foglalkoztatja az átmenet megsegítése (vö. Gyurcsik, 2020a, 2020b), ugyanakkor nem ismert, hogy a stakeholderek hogyan értelmezik az óvoda-iskola átmenet és az iskolaérettség fogalmát, milyen gyakorlatokkal próbálják segíteni az átmenetet, illetve milyen intézményi és szülői feladatokat azonosítanak a stakeholdereknek az átmenet megsegítésében. Ez a tanulmány ezek megismeréséhez, és az eredmények alapján nagymintás adatfelvételek megvalósításához teremt lehetőséget.

\section{Irodalom}

13/2018 (VI. 14.) EMMI rendelete a 2018/2019. tanév rendjéről. Magyar Közlöny, 85.

2011. évi CXC. törvény a nemzeti köznevelésről.

https://net.jogtar.hu/getpdf?docid=a1100190.tv\&targetdate $=\&$ printTitle=2011. $+\% \mathrm{C} 3 \% \mathrm{~A} 9 \mathrm{vi}+\mathrm{CXC} .+\mathrm{t} \% \mathrm{C} 3 \% \mathrm{~B} 6 \mathrm{rv} \% \mathrm{C} 3 \% \mathrm{~A} 9 \mathrm{ny}$

Antal, J. (2013). Hogyan és mikor lesz az óvodásból iskolás? Óvodai Nevelés, 66(4),2-4. Apró, M. (2013). A hazai iskolaérettségi vizsgálatok gyakorlata napjainkban. Iskolakultúra, 23(1), 52-71.

Commodari, E. (2013). Preschool teacher attachment, school readiness and risk of learning difficulties. Early Childhood Research Quarterly, 28(1), 123-133. https://doi.org/10.1016/j.ecresq.2012.03.004

Correia, K., \& Marques-Pinto, A. (2016). Adaptation in the transition to school: perspectives of parents, preschool and primary school teachers. Educational Research, 58(3), 247-264.

https://doi.org/10.1080/00131881.2016.1200255

Fabian, H. (2007). Informing Transitions. In Dunlop, A. \& Fabian, H. (Eds.), Informing transitions in the early years (pp. 3-17). Open University Press.

Futó, J. (2013). Nevelés színtere: család és óvoda. Óvodai Nevelés, 66(4), 28-29.

Gerebenné Várbíró, K. \& Vidákovich, T. (1997). A differenciált beiskolázás néhány méröeszköze: a Bender A-, a Budapesti Binet-, a Frostig-, a Goodenough-, a SONés a PREFER-tesztek összehasonlitó vizsgálata. Akadémiai Kiadó.

Gyurcsik, A. (2020a). Az óvoda-iskola átmenet óvodapedagógusok és tanitók szemével. XVIII. Pedagógiai Értékelési Konferencia. Elfogadott absztrakt.

Gyurcsik, A. (2020b). Az óvoda-iskola átmenet a szülők szemén keresztül. In Engler Á., Rébay, M. \& Tóth, D. A. (Eds.), Család a nevelés és az oktatás fókuszában: XX. Országos Neveléstudományi Konferencia: Absztraktkötet. Debreceni Egyetem, MTA Pedagógiai Tudományos Bizottság, Kopp Mária Intézet a Népesedésért és a Családokért, p. 383

Gyurcsik,A.,Fehér, O. \& Földi, F. (2017). Aziskolaérettség mérésénekösszehasonlítása Magyarországon és Szerbiában. Gyermeknevelés Tudományos Folyóirat, 5(3), 93-100.

https://doi.org/10.31074/gyntf.2017.3.93.100 
Hair, E., Halle, T. \& Humen, E. T. (2006). Children's school readiness in the ECLS- K: Predictions to academic, Health, and social outcomes in the first grade. Early Childhood Research Quarterly, 21(4), 431-454.

https://doi.org/10.1016/j.ecresq.2006.09.005

Heckman, J. J. (2011). The Economics of Inequality: The Value of Early Childhood Education. American Educator, 35(1), 31-35.

Józsa, K. (2004). Az első osztályos tanulók elemi alapkészségeinek fejlettsége - Egy longitudinális kutatás első mérési pontja. Iskolakultúra, 14(11), 3-16.

Józsa, K. (2007). Az elemi alapkészségek szerepe az olvasási képesség fejlődésében: egy longitudinális vizsgálat tapasztalatai. Szimpózium előadás. In Korom, E. (Ed.), PÉK 2007 - V. Pedagógiai Értékelési Konferencia: Program - Tartalmi összefoglalók. p. 55.

Józsa, K, (2016). Kihívások és lehetőségek az óvodai fejlesztésben. Iskolakultúra, 26(4), 59-74.

https://doi.org/10.17543/ISKKULT.2016.4.59

Józsa, K., Csima M., Nyitrai, Á. \& Podráczky, J. (2019). A korai fejlettségi mutatók szerepe az iskolai sikerességben: egy longitudinális kutatás első lépései. In Juhász, E. \& Endrődy, O. (Eds.), Oktatás - Gazdaság - Társadalom. HERA Évkönyvek. (pp. 848-860). VI. Magyar Nevelés- és Oktatáskutatók Egyesülete.

Kagan, S. L., Moore, E. \& Bredekamp, S. (1995). Reconsidering children's early learning and development: Toward shared beliefs and vocabulary. Report of the National Education Goals Panel. U.S. Government Printing Office.

Kende, A. \& Illés, A. (2007). A rugalmas beiskolázás és az oktatási szakadék összefüggései. Új Pedagógiai Szemle, 57(11), 17-41.

Mérei F. \& V. Binét, Á. (1978). Gyermeklélektan. Gondolat Kiadó.

Nagy, A. (2018). Harmonikus óvoda-iskola átmenet határon innen és túl. Paideia, 6(1), 179-194.

https://doi.org/10.33034/PAIDEIA.2018.6.1.179

Nagy, J. (1980). Az 5-6 éves gyermekeink iskolakészültsége. Akadémiai Kiadó.

Nagy, J. (1986). PREFER: Preventív fejlettségvizsgáló rendszer 4-7 éves gyermekek számára. Akadémiai Kiadó.

Nagy, J. (2003). Az eredményesebb képességfejlesztés feltételeiről és lehetőségeiről. Iskolakultúra,13(8), 40-52.

Nagy, J. (2012). Oktatási rendszerünk jövője. Sorsdöntő fejlesztési szükségletek és lehetőségek. Iskolakultúra, 22(3), 25-43.

Nagy, J., Józsa, K., Vidákovich, T. \& Fazekasné Fenyvesi, M. (2004). DIFER Programcsomag: Diagnosztikus fejlődésvizsgáló és kritériumorientált fejlesztő rendszer 4-8 évesek számára. Mozaik Kiadó.

Óvodai nevelés országos alapprogramja (2012). 363/2012. (XII. 17.) Korm. rendelet az Óvodai nevelés országos alapprogramjáról. https://net.jogtar.hu/ jogszabaly?docid=a1200363. kor 
Porkolábné Balogh, K., Balázsné Szűcs, J. \& Szaitzné Gregorits, A. (1997). Komplex prevenciós óvodai program „kudarc nélkül az iskolában”. Volán Humán Oktatási és Szolgáltató Rt.

Páli, J. (1997). Óvoda-iskola átmenet. In Báthory, Z. \& Falus, I. (Eds,), Pedagógiai lexikon. (pp. 93-94). Keraban Kiadó.

Ráczné Varga, Gy. (2007). Mit jelent az iskolaérettség. Óvodai Nevelés, 60(7), 239241.

Szabó, M. (2005). Az iskola kezdő szakasz helyzetének feltárása. Új Pedagógiai Szemle, (3), 80-97. 


\section{1. függelék}

Az óvoda-iskola átmenetet nehezitö tényezök és a megoldási javaslatok összefoglalása

\begin{tabular}{|c|c|c|c|c|}
\hline \multirow{2}{*}{$\begin{array}{l}\text { Átmenetet } \\
\text { nehezítő } \\
\text { tényezook }\end{array}$} & \multirow[b]{2}{*}{$\begin{array}{c}\text { Minta (válaszadók } \\
\text { aránya) }\end{array}$} & \multicolumn{3}{|c|}{ Melyik intézmény tud segíteni? } \\
\hline & & $\begin{array}{l}\text { Óvodapedagó- } \\
\text { gus (válaszadók } \\
\text { aránya) }\end{array}$ & $\begin{array}{l}\text { Tanító (válasz- } \\
\text { adók aránya) }\end{array}$ & $\begin{array}{l}\text { Szülő (válasz- } \\
\text { adók aránya) }\end{array}$ \\
\hline $\begin{array}{l}\text { A játékot fel- } \\
\text { váltja a tanulás }\end{array}$ & $\begin{array}{l}\text { óvodapedagógus (5); } \\
\text { tanító (4); } \\
\text { szülő (5) }\end{array}$ & iskola (5) & $\begin{array}{l}\text { iskola (2); } \\
\text { óvoda (2) }\end{array}$ & iskola (5) \\
\hline $\begin{array}{l}\text { Kötelező jel- } \\
\text { legű iskolai } \\
\text { foglalkozások }\end{array}$ & $\begin{array}{l}\text { óvodapedagógus (5); } \\
\text { tanító (3); } \\
\text { szülö (3) }\end{array}$ & iskola (5) & $\begin{array}{l}\text { iskola (2); óvoda } \\
\text { (1) }\end{array}$ & iskola (4) \\
\hline $\begin{array}{l}\text { Feszített tanu- } \\
\text { lási tempó van } \\
\text { az iskolában }\end{array}$ & $\begin{array}{l}\text { óvodapedagógus (3); } \\
\text { tanító (2); } \\
\text { szülő (4) }\end{array}$ & iskola (3) & iskola (2) & iskola (4) \\
\hline $\begin{array}{l}\text { Idegen, isme- } \\
\text { retlen az iskola } \\
\text { épülete és } \\
\text { tanítók }\end{array}$ & $\begin{array}{l}\text { óvodapedagógus (5); } \\
\text { tanító (5); } \\
\text { szülő (4) }\end{array}$ & $\begin{array}{l}\text { óvoda és iskola } \\
\text { együtt (5) }\end{array}$ & $\begin{array}{l}\text { óvoda és iskola } \\
\text { együtt (5) }\end{array}$ & $\begin{array}{l}\text { óvoda és iskola } \\
\text { együtt (5) }\end{array}$ \\
\hline $\begin{array}{l}\text { Teljesítmény- } \\
\text { orientáció } \\
\text { kerül előtérbe }\end{array}$ & $\begin{array}{l}\text { óvodapedagógus (4); } \\
\text { tanító (4); } \\
\text { szülö (5) }\end{array}$ & iskola (4) & iskola (4) & iskola (4) \\
\hline $\begin{array}{l}\text { Osztályozás } \\
\text { megjelenése, } \\
\text { rendszeres } \\
\text { értékelés }\end{array}$ & $\begin{array}{l}\text { óvodapedagógus (3); } \\
\text { tanító (4); } \\
\text { szülő (5) }\end{array}$ & iskola (3) & iskola (4) & iskola (5) \\
\hline $\begin{array}{l}\text { Szigorú, kötött } \\
\text { iskolai szabá- } \\
\text { lyok }\end{array}$ & $\begin{array}{l}\text { óvodapedagógus (4); } \\
\text { tanító (4); } \\
\text { szülö (5) }\end{array}$ & iskola (4) & $\begin{array}{l}\text { óvoda (2); iskola } \\
\text { (2) }\end{array}$ & iskola (5) \\
\hline $\begin{array}{l}\text { Együttmű- } \\
\text { ködés hiánya } \\
\text { az érintett } \\
\text { pedagógusok } \\
\text { között }\end{array}$ & $\begin{array}{l}\text { óvodapedagógus (4); } \\
\text { tanító (4); szülő (3) }\end{array}$ & $\begin{array}{l}\text { óvoda és iskola } \\
\text { együtt (4) }\end{array}$ & $\begin{array}{l}\text { óvoda és iskola } \\
\text { együtt (4) }\end{array}$ & $\begin{array}{l}\text { óvoda és iskola } \\
\text { együtt (4) }\end{array}$ \\
\hline $\begin{array}{l}\text { Együttműkö- } \\
\text { dés hiánya az } \\
\text { érintett pe- } \\
\text { dagógusok és } \\
\text { szülők között }\end{array}$ & $\begin{array}{l}\text { óvodapedagógus (3); } \\
\text { tanító (2); szülő (1) }\end{array}$ & $\begin{array}{l}\text { óvoda és szülő } \\
\text { együtt (3) }\end{array}$ & $\begin{array}{l}\text { iskola és szülő } \\
\text { együtt (3) }\end{array}$ & $\begin{array}{l}\text { óvoda, iskola és } \\
\text { szülő együtt (1) }\end{array}$ \\
\hline
\end{tabular}




\begin{tabular}{|l|l|l|l|l|}
\hline $\begin{array}{l}\text { A gyerekek } \\
\text { nem önállóak } \\
\text { (pl. nem tud- } \\
\text { nak orrot fújni) }\end{array}$ & $\begin{array}{l}\text { óvodapedagógus (0); } \\
\text { tanító (4); szülő (0) }\end{array}$ & - & $\begin{array}{l}\text { óvoda (2); szülő } \\
(2)\end{array}$ & - \\
\hline $\begin{array}{l}\text { A gyerekek } \\
\text { nem együtt- } \\
\text { múködőek }\end{array}$ & $\begin{array}{l}\text { óvodapedagógus (0); } \\
\text { tanító (3); szülő (0) }\end{array}$ & - & óvoda (3) & - \\
\hline $\begin{array}{l}\text { A gyerekek } \\
\text { nehezen alkal- } \\
\text { mazkodnak a } \\
\text { szabályokhoz }\end{array}$ & $\begin{array}{l}\text { óvodapedagógus (2); } \\
\text { tanító (4); szülő (0) }\end{array}$ & n.a. & n.a & - \\
\hline
\end{tabular}

\begin{tabular}{|c|c|c|c|c|}
\hline \multirow[b]{2}{*}{$\begin{array}{l}\text { Átmenetet } \\
\text { nehezítő té- } \\
\text { nyezők }\end{array}$} & \multirow[b]{2}{*}{$\begin{array}{c}\text { Minta (válaszadók } \\
\text { aránya) }\end{array}$} & \multicolumn{3}{|c|}{ Hogyan? } \\
\hline & & $\begin{array}{c}\text { Óvoda- } \\
\text { pedagógus } \\
\text { (válaszadók } \\
\text { aránya) }\end{array}$ & $\begin{array}{c}\text { Tanító } \\
\text { (válaszadók } \\
\text { aránya) }\end{array}$ & $\begin{array}{c}\text { Szülő } \\
\text { (válaszadók } \\
\text { aránya) }\end{array}$ \\
\hline $\begin{array}{l}\text { A játékot fel- } \\
\text { váltja a tanulás }\end{array}$ & $\begin{array}{l}\text { óvodapedagógus (5); } \\
\text { tanító (4); } \\
\text { szülő (5) }\end{array}$ & $\begin{array}{l}\text { játékos iskolai } \\
\text { foglalkozások } \\
\text { bevezetése (3); } \\
\text { óvodai környe- } \\
\text { zethez hasonló } \\
\text { iskolai környezet } \\
\text { megteremtése (2); } \\
\text { lassabb tanulási- } \\
\text { tanítási tempó (1) }\end{array}$ & $\begin{array}{l}\text { játékos iskolai } \\
\text { foglalkozások (2); } \\
\text { kötelező jellegü } \\
\text { óvodai foglalko- } \\
\text { zások bevezetése } \\
\text { (2) }\end{array}$ & $\begin{array}{l}\text { játékos iskolai } \\
\text { foglalkozások } \\
\text { bevezetése (5) }\end{array}$ \\
\hline $\begin{array}{l}\text { Kötelező jel- } \\
\text { legű iskolai } \\
\text { foglalkozások }\end{array}$ & $\begin{array}{l}\text { óvodapedagógus (5); } \\
\text { tanító (3); } \\
\text { szülő (3) }\end{array}$ & $\begin{array}{l}\text { játékos iskolai } \\
\text { foglalkozások } \\
\text { bevezetése (3); } \\
\text { választási lehető- } \\
\text { ség a foglalkozá- } \\
\text { sok közül (2) }\end{array}$ & $\begin{array}{l}\text { iskolai beszok- } \\
\text { tatási időszak } \\
\text { megnyújtása (2); } \\
\text { kötelező óvodai } \\
\text { foglalkozások } \\
\text { bevezetése (1) }\end{array}$ & $\begin{array}{l}\text { választási lehető- } \\
\text { ség a foglalkozá- } \\
\text { sok közül (2); } \\
\text { változatos, rövid } \\
\text { foglalkozások } \\
\text { bevezetése (1) }\end{array}$ \\
\hline $\begin{array}{l}\text { Feszített tanu- } \\
\text { lási tempó van } \\
\text { az iskolában }\end{array}$ & $\begin{array}{l}\text { óvodapedagógus (3); } \\
\text { tanító (2); } \\
\text { szülő (4) }\end{array}$ & $\begin{array}{l}\text { a tananyag játékos } \\
\text { feldolgozása (2); } \\
\text { sok szünet (3) }\end{array}$ & $\begin{array}{l}\text { a tanagyag játékos } \\
\text { feldolgozása (2) }\end{array}$ & $\begin{array}{l}\text { a tananyag meg- } \\
\text { tanulása lassabb } \\
\text { tempóban (2); az } \\
\text { elvárások csök- } \\
\text { kentése (2) }\end{array}$ \\
\hline $\begin{array}{l}\text { Idegen, isme- } \\
\text { retlen az iskola } \\
\text { épülete és } \\
\text { tanítók }\end{array}$ & $\begin{array}{l}\text { óvodapedagógus (5); } \\
\text { tanító (5); } \\
\text { szülő (4) }\end{array}$ & $\begin{array}{l}\text { iskolai nyílt nap } \\
\text { (3); tanító óvodai } \\
\text { látogatása (3); } \\
\text { közös óvodai és } \\
\text { iskolai ünnepsé- } \\
\text { gek (2) }\end{array}$ & $\begin{array}{l}\text { közös óvodai és } \\
\text { iskolai ünnepsé- } \\
\text { gek (4); } \\
\text { iskolai nyílt nap } \\
\text { (3) }\end{array}$ & $\begin{array}{l}\text { iskolai nyílt nap } \\
\text { (4); } \\
\text { tanító óvodai } \\
\text { látogatása (3) }\end{array}$ \\
\hline $\begin{array}{l}\text { Teljesítmény- } \\
\text { orientáció } \\
\text { kerül elötérbe }\end{array}$ & $\begin{array}{l}\text { óvodapedagógus (4); } \\
\text { tanító (4); } \\
\text { szülő (5) }\end{array}$ & $\begin{array}{l}\text { elvárások mérté- } \\
\text { kének csökkenté- } \\
\text { se az első félévben } \\
\text { (4) }\end{array}$ & n.a. & n.a \\
\hline
\end{tabular}




\begin{tabular}{|c|c|c|c|c|}
\hline $\begin{array}{l}\text { Osztályozás } \\
\text { megjelenése, } \\
\text { rendszeres } \\
\text { értékelés }\end{array}$ & $\begin{array}{l}\text { óvodapedagógus (3); } \\
\text { tanító (4); } \\
\text { szülő (5) }\end{array}$ & $\begin{array}{l}\text { szöveges értékelés } \\
\text { alkalmazása (2); } \\
\text { jutalmazás (1) }\end{array}$ & $\begin{array}{l}\text { egyéni fejlődés } \\
\text { értékelése (4); } \\
\text { jutalmazás, dicsé- } \\
\text { ret (3); } \\
\text { szöveges értéke- } \\
\text { lés (3) }\end{array}$ & dicséret (5) \\
\hline $\begin{array}{l}\text { Szigorú, kötött } \\
\text { iskolai szabá- } \\
\text { lyok }\end{array}$ & $\begin{array}{l}\text { óvodapedagógus (4); } \\
\text { tanító (4); } \\
\text { szülő (5) }\end{array}$ & $\begin{array}{l}\text { óvodai szabályok } \\
\text { átvétele az első } \\
\text { félévben (3); } \\
\text { közös szabályal- } \\
\text { kotás a gyerekkel } \\
\text { (3) }\end{array}$ & $\begin{array}{l}\text { az óvodai szabá- } \\
\text { lyok szigorítása a } \\
\text { nagycsoportban } \\
(2) ; \\
\text { közös szabályal- } \\
\text { kotás a gyerekek- } \\
\text { kel (2) }\end{array}$ & $\begin{array}{l}\text { óvodai szabá- } \\
\text { lyokhoz hasonló } \\
\text { szabályok kidol- } \\
\text { gozása (5) }\end{array}$ \\
\hline $\begin{array}{l}\text { Együttműkö- } \\
\text { dés hiánya az } \\
\text { érintett peda- } \\
\text { gógusok között }\end{array}$ & $\begin{array}{l}\text { óvodapedagógus (4); } \\
\text { tanító (4); szülö (3) }\end{array}$ & $\begin{array}{l}\text { egymás kölcsönös } \\
\text { felkeresése }(2) ; \\
\text { közös programok } \\
\text { szervezése }(2)\end{array}$ & $\begin{array}{l}\text { intézménylátoga- } \\
\text { tások (2); közös } \\
\text { programok (1); } \\
\text { egymás felkeresé- } \\
\text { se (1) }\end{array}$ & $\begin{array}{l}\text { közös programok } \\
\text { (3) }\end{array}$ \\
\hline $\begin{array}{l}\text { Együttműkö- } \\
\text { dés hiánya az } \\
\text { érintett pe- } \\
\text { dagógusok és } \\
\text { szülők között }\end{array}$ & $\begin{array}{l}\text { óvodapedagógus (3); } \\
\text { tanító (2); szülő (1) }\end{array}$ & $\begin{array}{l}\text { másik álláspont- } \\
\text { jának elfogadása } \\
\text { (2); a pedagógu- } \\
\text { sok észrevételei- } \\
\text { nek elfogadása (2) }\end{array}$ & $\begin{array}{l}\text { a pedagógusok } \\
\text { észrevételeinek } \\
\text { elfogadása (2) }\end{array}$ & $\begin{array}{l}\text { problémák közös } \\
\text { megbeszélése (1) }\end{array}$ \\
\hline $\begin{array}{l}\text { A gyerekek } \\
\text { nem önállóak } \\
\text { (pl. nem tud- } \\
\text { nak orrot fújni) }\end{array}$ & $\begin{array}{l}\text { óvodapedagógus }(0) \text {; } \\
\text { tanító (4); szülő }(0)\end{array}$ & - & $\begin{array}{l}\text { hagyni, hogy a } \\
\text { gyermek önmagát } \\
\text { lássa el (4) }\end{array}$ & - \\
\hline $\begin{array}{l}\text { A gyerekek } \\
\text { nem együttmü- } \\
\text { ködőek }\end{array}$ & $\begin{array}{l}\text { óvodapedagógus (0); } \\
\text { tanító (3); szülő (0) }\end{array}$ & - & $\begin{array}{l}\text { csoportmunka } \\
\text { alkalmazása az } \\
\text { óvodában (3) }\end{array}$ & - \\
\hline $\begin{array}{l}\text { A gyerekek } \\
\text { nehezen alkal- } \\
\text { mazkodnak a } \\
\text { szabályokhoz }\end{array}$ & $\begin{array}{l}\text { óvodapedagógus (2); } \\
\text { tanító (4); szülő (0) }\end{array}$ & n.a & n.a & - \\
\hline
\end{tabular}

Megjegyzés: nincs adat=nem tudtak választ adni 


\section{Gyurcsik, A.}

\section{The transition from kindergarten to school through the eyes of kindergarten teachers, school teachers and parents}

This study is about the presentation of an exploratory research that will serve as a basis for the design of subsequent large-sample surveys. I conducted semi-structured interviews with kindergarten teachers $(\mathrm{N}=5)$, school teachers $(\mathrm{N}=5)$, and parents with first-grade children $(\mathrm{N}=5)$ to explore their interpretation and practice of the transition between kindergarten and school. Respondents see some of the difficulties encountered during the kindergarten-school transition in a similar way, however, I did not receive very definite answers regarding the possible solutions to these difficulties. When children start school, different skills may be important, and school maturity is determined only by the methods used in the given institution. According to the respondents, they are trying to make the kindergarten-school transition smoother by introducing the school to the children and allowing them to meet their future teacher. Interviewees identified pretty similar institutional and parenting roles in assisting the transition. With the help of my results the parental views can be supported by arguments, it can also help the work of the teachers, and can make it more effective.

Keywords: kindergarten school transition, school readiness, stakeholders' views, starting school, transition into primary school

Gyurcsik Anita: https://orcid.org/0000-0003-4353-2720 